\title{
The Search for a New Economic System Continues
}

\section{INTRODUCTION}

Much work has been done in South Africa and indeed everywhere in the world to close both the intellectual and the policy gap in the understanding of the interface between the economic and environmental systems. How far has this search progressed? Some will argue very far. They will quote the increasing importance of carbon trading and the introduction of international treaties such as the convention on biological diversity and the Kyoto protocol as important milestones and a watershed. The notion of clean technology has also begun to penetrate the marketing arena under green labelling or branding and as such has considerable financial value for a firm.

Without detracting from these successes, actually in an effort to support and intensify the current research and policy trend, this editorial adopts a rather different view, asking the question: has economic theory changed symbiotically to the change in world philosophy that took place during the last number of years? Unfortunately the answer to this question is negative.

In addressing these issues, the origins of modern economics are briefly examined. Thereafter, the change in current philosophy and by contrast, the stagnation of economic theory are discussed and a brief look at the ongoing research trends concludes.

\section{THE ORIGINS OF RATIONAL SELF-INTEREST}

The 1700s witnessed a change in the general philosophy or world-view of the time. The incumbent philosophy accentuated the importance of the human ability to reason, of individual freedom and the fulfilment that man had to derive from life itself. This new philosophy was personified by Jean Jacques Rousseau (1712-1778) and neither the dwindling influence of the Roman Catholic Church nor the fledgling Reformation movement at that stage could change or halt this surge in humanism (Schumpeter, 1954: 107-15). It was in this climate that Adam Smith (1723-1790) wrote An Inquiry into the Wealth of Nations (1776). It is therefore not surprising that Smith accentuated individual self-interest, savings, capital accumulation and the division of labour as necessary factors to accomplish the set ideal of increased national product (or economic growth). A deterministic 
Newtonian self-regulatory mechanism, an invisible hand, i.e. the market forces, would ensure this required economic growth (Heilbroner, 1985: 65-66). Heilbroner refers to this Smithsonian economic system as a growth model, illustrating it as a propulsive force that will put society on an upward growth path, as well as a self-correcting mechanism that will keep it there. Ever since Smith, this underlying philosophy has not changed, as clearly highlighted by Shiva (1988; xvi-xvii):

The rise of a patriarchal science of nature took place in Europe during the fifteenth and seventeenth centuries as the scientific revolution. During the same period, the closely-related Industrial Revolution laid the foundation of a patriarchal mode of economic development in industrial capitalism. Contemporary science and development conserve the ideological root and biases of the scientific and Industrial Revolution even as they unfold into new areas of activity and new domains of subjugation.

Long before Shiva, however, Schumacher (1973: 13) has foretold the potential impact of this Smithsonian system of subjugation:

Modern man does not experience himself as a part of nature but as an outside force destined to dominate and to conquer it. He even talks of a battle with nature, forgetting that if he won the battle, he would find himself on the losing side. Until quite recently, the battle seemed to go well enough to give him the illusion of unlimited powers, but not so well as to bring the possibility of total victory into view. This has now come into view, and many people, albeit only a minority, are beginning to realise what this means for the continued existence of humanity.

Today the evidence or result of the battle between man and nature that Schumacher has referred to, is all around us and highlighted in all the articles in this volume. But why the perpetuation of this system that is threatening the existence of humanity?

\section{FROM RATIONAL SELF-INTEREST TO A SEARCH FOR A NEW DESIGN}

Smith introduced a new and modemistic economic system during a time when the global world-view or philosophy changed. Not unlike the era during which Smith lived and wrote, post-modernism is currently replacing modernism. The differences between these two opposing world-views are summarised in Table 1 . 


\section{Table 1 Modernism and Post-Modernism}

\begin{tabular}{|l|l|}
\hline \multicolumn{1}{|c|}{ Modern paradigm } & \multicolumn{1}{|c|}{ Post-modern paradigm } \\
\hline $\begin{array}{l}\text { Human being as a rational, autonomous } \\
\text { being }\end{array}$ & Human being as a relational being \\
$\begin{array}{l}\text { Universe (nature) as object of the needs } \\
\text { of the human being }\end{array}$ & $\begin{array}{l}\text { Universe (nature) as a dynamic } \\
\text { organism }\end{array}$ \\
\hline $\begin{array}{l}\text { Absolute, deterministic influence of } \\
\text { science and technology }\end{array}$ & Science: chaos and qualitative \\
\hline $\begin{array}{l}\text { General optimism with regard to the } \\
\text { prospects of development and growth - } \\
\text { i.e. improvement }\end{array}$ & and limitations \\
\hline $\begin{array}{l}\text { Truth as objective and neutral } \\
\text { Cosmological view }\end{array}$ \\
\hline Stable & $\begin{array}{l}\text { Truth, objectivity and neutrality } \\
\text { subject to the role of belief and value } \\
\text { systems }\end{array}$ \\
\hline Closed & Open (holistic) \\
\hline Determined & Relative/randomness/ indeterminacy \\
\hline Predictable/measurable/controllable & Complex \\
\hline
\end{tabular}

Adapted from: Söhnge (1995)

The impact of this change from modernism to post-modernism is visible over a wide front, as is shown in Table 2 with regard to corporate management systems.

From Table 2 it is clear that the management style of the $21^{\text {st }}$ century did not just amend the $20^{\text {th }}$ century management style - it is a completely new design. The problem, however, in economics is that a post-modern replacement (or new design) for the Smithsonian system is still to be found. This search for a postmodern economic system resembles the search for a unified theory of gravity as illustrated in A Brief Histony of Time by Hawking (1988). Modern-day economics, still taught in almost all universities of repute, is based on the microeconomic premise that the collective outcome of rational individual decisions in pursuit of self-interest for the maximisation of either producer or consumer surplus will lead to optimal resource allocation and efficiency. This premise, however, relies heavily on a large number of assumptions. Failure to uphold them will inevitably lead to failure on a larger scale - and to negative environmental externalities. From a macroeconomic perspective, the natural environment is treated equally neatly under the ceteris paribus clause, as if the stock and quality of natural resources do not change. 
Table 2 Comparison between two management and organisational behaviour styles

\begin{tabular}{|l|l|l|}
\hline \multicolumn{1}{|c|}{ Characteristics } & \multicolumn{1}{|c|}{$\begin{array}{c}\mathbf{2 0}^{\text {thi }} \text { Century } \\
\text { corporation }\end{array}$} & $\mathbf{2 1}^{\text {st }}$ Century corporation \\
\hline Organisation & The pyramid & The web or network \\
\hline Reach & Domestic & Global \\
\hline Focus & Internal & External \\
\hline Structure & Self-sufficiency & Interdependencies \\
\hline Operations & Vertical integration & Virtual integration \\
\hline Resources & Atoms: physical assets & Bits - information \\
\hline Source of strength & Stability & Change \\
\hline Style & Structured & Flexible \\
\hline Leadership & Dogmatic & Inspirational \\
\hline Motivation & To complete & To build \\
\hline Workers & Employees & $\begin{array}{l}\text { Employees } \\
\text { (outsourcing) }\end{array}$ \\
\hline Job expectations & Security & Personal growth \\
\hline Strategy & Top-down & Bottom-up \\
\hline Products & Mass production & Mass customisation \\
\hline Financials & Quarterly & Real-time \\
\hline Inventories & Months & Hours \\
\hline Improvements & Incremental & Revolutionary \\
\hline Quality & Affordable best & No compromise \\
\hline
\end{tabular}

Source: Bryne (2000)

Frequent attempts have been made to rectify some of the problems intrinsic in the system; for example the work by Pigou (1932) with regard to environmental taxes and by Coase (1960) with regard to property rights and externalities. A large number of similar attempts to address the deficiencies in the Smithsonian system across a wide variety of fields are also currently in progress. These attempts may be compared to sincere efforts to improve the efficiency of the internal combustion engine of a motorcar by, among others, improvements in its catalytic converter, but it still remains an intemal combustion engine running on fossil fuel. It therefore does not reflect a new engine design, just an improved internal combustion engine.

\section{WHERE ARE THE ANSWERS?}

The search for a new design of the economic system will invariably, first and foremost, lead to a discussion regarding sustainable development. The concept of sustainable development is hard to comprehend and allows very different interpretations varying from the classical Brundtland definition of sustainable 
development (development that will not compromise future development) to sustainable returns to shareholders. It should be clear following from the vastly different definitions of sustainable development that the debate is also often nuanced by different political and institutional agendas. More often than not, these agendas reflect the power of vested interests, historic inequalities or biases, dogmatism and inability or unwillingness to change. The net effect is a general perpetuation of the old system with some isolated changes visible on the fringes. As yet, sustainable development, irrespective of the definition used, remains a dream, a vision, and does not represent a departure from the theoretic principles upon which current economics are built. Consider again the analogy with the combustion engine.

On another level, there are individuals and even institutions who devote their time and effort to a sincere search for solutions. Classic examples of these are Hawkin, Lovins and Lovins (2000) and Brown (2001), who attempted to reveal a picture of how some technological changes (which are currently feasible) combined with certain policy changes can lead to a new way of production and a lower level of resource consumption without compromising quality of life. These attempts, though praiseworthy and supported morally and practically, do not resemble (and were never intended to be) a new economic theory.

The problem is that, without a new economic theory, the old problems and systems will persist. While the search goes on, only the quality of the catalytic converter improves, but the design remains unchanged, to re-use the earlier analogy. The search for a new economic theory that can replace the Smithsonian system therefore continues.

\section{LIVING WITH THE SEARCH}

While the search for an economic system and theory continues, every possible effort should be made to reduce the ecological footprint of the current generation. To this end, this volume contributes by addressing aspects such as whether environmental issues can wait until development has taken place, followed by a search for solutions and a number of case studies. A variety of issues are addressed such as climate change, trade and the environment, water resource as well as land use management. These examples serve to illustrate that even while the search for a redesigned economic theory is underway, notable progress can be made towards improvement in quality of life, alleviation of poverty and the proper and appropriate use of natural resources.

\section{J N Blignaut}

Professor of Economics, University of Pretoria 


\section{REFERENCES}

1 BROWN, L. (2001) Eco-Economics, New York: Norton.

2 BYRNE, J.A. (2000) Business Week, 21-28 August.

3 COASE, R. (1960) "The Problem of Social Cost", The Journal of Law and Economics, 3: 1-44.

4 HAWKEN, P, LOVINS, A. \& LOVINS, L. (2000) Natural Capitalism: The Next Industrial Revolution, London: Earthscan.

5 HAWKING, S. (1988) A Brief History of Time, London: Bantam Press.

6 PIGOU, A.C. (1932) The Economics of Welfare, London: Macmillan.

7 SCHUMACHER, E.F. (1973) Small is Beautiful, London: Harper and Row.

8 SCHUMPETER, J.A. (1954) History of Economic Analysis, Oxford: Oxford University Press.

9 SHIVA, V. (1988) Staying Alive, London: Zed Books.

10 SÖHNGE, W.F. (1995) "Education and Political Transition: A Transformational or Paradigmatic Issue?" SASE 21st Anniversary Conference: Windhoek. 